\title{
Hyperpycnites within the Devonian-Carboniferous flysch of the Carpatho-Balkanides (Kostadinovica, eastern Serbia)
}

\author{
Miloš Radonjić \\ University of Belgrade, Faculty of Mining and Geology, Department of Regional Geology, Kamenička 6, 11000 Belgrade, Serbia; (milos.radonjic@rgf.bg.ac.rs)
}

doi: $10.4154 / g c .2020 .13$

Article history:

Manuscript received April 15, 2020

Revised manuscript accepted August 25, 2020

Available online October 22, 2020

\begin{abstract}
This study presents new discoveries of vascular plants and the trace fossil Dictyodora liebeana (GEINITZ) from the Devonian-Carboniferous Kučaj-Zvonce flysch of the Carpatho-Balkanides and the implications of this fossil association for its sedimentary setting. The occurrence of the described plant debris in a deep-marine environment indicates the presence of hyperpycnites within the siliciclastic turbidites exposed at the Kostadinovica locality. The sedimentological data and the characteristics of the fossil material support the proposed model in which the sediment was at least partially transported by hyperpycnal currents. Furthermore, based on the assessment to similar palaeofloras from comparable formations, the age of the fossil plants can be determined as Early Carboniferous. This can be used as an additional biostratigraphic criterion given the relative abundance of vascular plants in other localities of the Kučaj-Zvonce flysch described in previous studies. The age and the depositional setting of the succession is further better constrained by the first observation of Dictyodora liebeana (GEINITZ) in the CarpathoBalkanides of Serbia.
\end{abstract}

Keywords: Mississippian flora, Dictyodora liebean (GEINITZ), hyperpycnites, Kučaj-Zvonce flysch, Carpatho-Balkanides

\section{INTRODUCTION}

The Middle Devonian to Early Carboniferous turbiditic siliciclastic succession of the central part of the Carpatho-Balkanides of Serbia is classically interpreted as the Kučaj-Zvonce flysch (MASLAREVIĆ \& KRSTIĆ, 1987a). In addition to previously documented sedimentological data from several localities in Serbia (e.g. KRSTIĆ, 1984; KRSTIĆ et al., 2004, 2005), the concept of extrabasinal turbidites (ZAVALA \& ARCURI, 2016) produced under hyperpycnal flows is discussed as an additional point to the overall interpretation of the system. As the hyperpycnal flows occur during high river discharge into the basin they represent an efficient mechanism of transfer of clastic material from continental environments to the deep-marine realms (MULDER \& SYVITSKI, 1995). The characteristics of hyperpycnites (deposits of hyperpycnal flows) are distinctive both in their sedimentological features (MULDER et al., 2003) and palaeontological content (ZAVALA et al., 2012). These diagnostic criteria were used to indicate the presence of hyperpycnites within the turbidites of the Kučaj-Zvonce flysch.

The characteristics of the Kučaj-Zvonce flysch were studied at the Kostadinovica quarry in which $31.75 \mathrm{~m}$ of the siliciclastic succession is exposed. Analyzed sedimentary features were used for the determination of lithofacies and their internal relationships. Observed sedimentary characteristics along with palaeontological material from the site were further compared to criteria for the genetic model of extrabasinal turbidites (ZAVALA \& PAN, 2018) with the aim of better understanding the processes controlling the deposition.

The age of the studied succession at Kostadinovica has not been determined more precisely by previous studies due to the lack of biostratigraphic indicators from the site but has rather been derived from comparison of the lithostratigraphic characteristics with other localities (VESELINOVIĆ et al., 1964a). Pioneering palaeobotanical data from the Devonian of the Carpatho-Balkanides (PANTIĆ, 1960) was often used as one of the age criteria for similar occurrences of the Kučaj-Zvonce flysch, while in most cases the age has been broadly determined as Devonian. The proposed Devonian age of the Kostadinovica succession was likewise set earlier based on the relatively abundant vascular plants from the site (KRSTIĆ, 1984). This paper presents the first discovery of the trace fossil Dictyodora liebeana (GEINITZ) from the Carpatho-Balkanides of Serbia which is used both as an indicator for a deep-marine depositional environment and also to propose an Early Carboniferous age for the succession. Furthermore, the collected palaeobotanical material is compared to similar Mississippian floras of Europe.

Based on the studied sedimentary features and the position and mode of preservation of the palaeontological material, the Kostadinovica succession is interpreted as an distal part of the turbidite system with the occurrence of hyperpycnites. The detailed discrimination between depositional sequences (turbidites versus hyperpycnites) resulting from their fundamentally different modes of transport was limited by the insufficient quantity of the obtained sedimentological samples. This led to the use of fossils as an indicator of hyperpycnal transport. The presented study could be used as a starting point for a more detailed petrological analysis of the provenance of the detrital components combined with palaeogeographical information. A further aim should be a reconstruction of the hinterland area of the system which is also lacking at present. Although the framework of the Devonian/Carboniferous flysch systems of SE Europe was developed and compared at regional scales (EBNER et al., 2008; VOZÁROVÁ et al., 2009), local studies in the Carpatho-Balkanides could lead to a better understanding of the Kučaj-Zvonce flysch and its position and correlation to other equivalent formations of the Variscides of Europe.

\section{GEOLOGIC SETTING}

The studied succession at the Kostadinovica locality is positioned in the central part of the Carpatho-Balkanides in eastern Serbia 


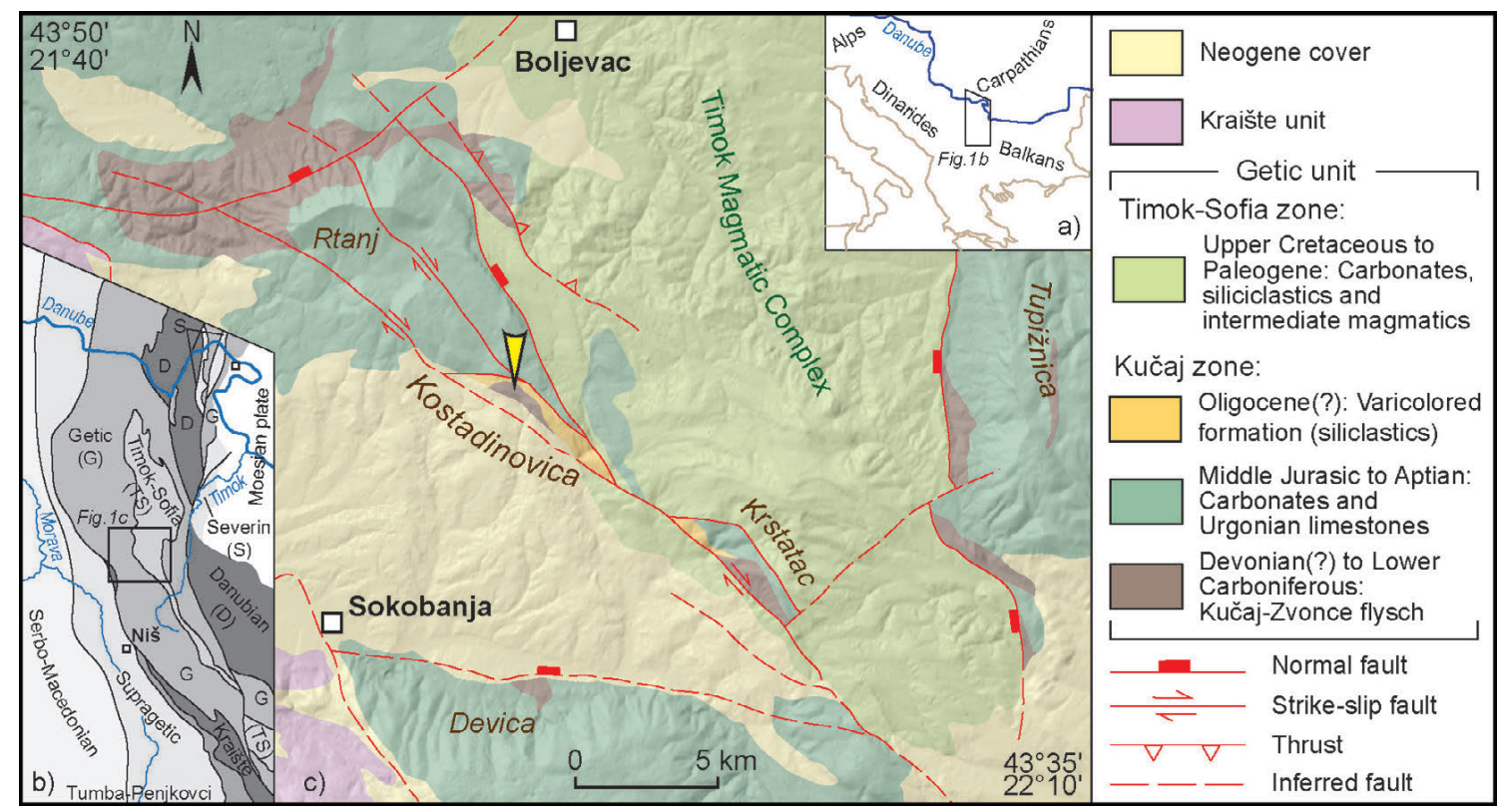

Figure 1. The position of the Kostadinovica section. (a) Outline of SE Europe and the position of the Carpatho-Balkanides in Serbia. (b) Tectonic units of the Carpatho-Balkanides (modified after KRÄUTNER \& KRSTIĆ, 2002). (c) Geological sketch map of the studied area (modified after VESELINOVIĆ et al., 1964b; KRÄUTNER \& KRSTIĆ, 2003). Arrow indicates the position of the studied section.

(Fig. 1a, b). In terms of the Alpine orogeny, the Kučaj-Zvonce flysch is part of the basement of the Getic unit (i.e. KRÄUTNER \& KRSTIĆ, 2002; KRSTEKANIĆ et al., 2017; SCHMID et al., 2020) or the locally termed Kučaj Zone (DIMITRIJEVIĆ, 1997). The Kučaj zone is characterized by magmatic rocks and sedimentary formations with diverse histories both in terms of metamorphism and tectonics. The oldest formations belong to the Proterozoic-Cambrian crystalline metamorphics of the Homoljske Mts. in the northern part of the unit (DIMITRIJEVIĆ, 1997). The overlying deposits represent a siliciclastic cycle of sedimentation with a trend of deepening of the facies beginning with Early Ordovician coastal/shallow marine siliciclastics which pass into deep basinal Silurian to Early Devonian fine-grained graptolite schists (KRSTIĆ \& MASLAREVIĆ, 1990). The Devonian (Late Lochkovian to Late Frasnian) Pre-flysch is defined as channeled slope facies with the addition of hemipelagic shales, cherts and limestones (KRSTIĆ et al., 2004) which terminates with dolomitic limestones containing conodonts of the gigas and linguliformis zones of the Late Frasnian (KRSTIĆ \& SUDAR, 1989).

The deposition of the Kučaj-Zvonce flysch lasted from the Late Devonian (late Frasnian) to the Early Carboniferous (Viséan) as a part of the circum Pannonian flysch system (EBNER et al., 2008). The Kučaj-Zvonce flysch was interpreted as a retrograding system of deposits of the slope to mid-fan and the outerfan to basin tract (KRSTIĆ et al., 2004). The Bouma divisions were used for the description of the sedimentary sequences with emphasized examples of the $\mathrm{T}_{\mathrm{bcd}}, \mathrm{T}_{\mathrm{abcd}}$ and $\mathrm{T}_{\mathrm{bcde}}$ intervals as a general trend for this unit (KRSTIĆ et al., 2008). Among other sedimentological constituents of the flysch, Lower Carboniferous limestone olistosromes of $\mathrm{cm}$ to $\mathrm{m}$ dimensions were discovered (MASLAREVIĆ \& KRSTIĆ, 1987b). The Kučaj-Zvonce flysch is unconformably overlain by Upper Carboniferous continental deposits, Permian red sandstones and Mesozoic-Palaeogene sedimentary cover (KRSTIĆ \& MASLAREVIĆ, 1990).

\section{THE KOSTADINOVICA SECTION}

The exposed succession at the Kostadinovica locality (WGS: $43^{\circ} 43^{\prime} 5.06^{\prime \prime} \mathrm{N} ; 21^{\circ} 56^{\prime} 38.90^{\prime \prime} \mathrm{E}$ ) is in probable tectonic contact with Cretaceous carbonates and Oligocene(?) siliciclastics towards the NE side of its exposure while the Neogene sediments of the Sokobanja basin transgressively overlie it towards the SW (Fig.1c). The Kostadinovica quarry exposes some $31.75 \mathrm{~m}$ of the siliciclastics sequence (Fig. 2). In the field, the observed rocks were categorized predominantly as siltstones to medium-grained sandstones (STOW, 2005). The sandstones are mostly very fineto medium-grained greywackes (KRSTIĆ, 1984). Grains are relatively poorly sorted and composed mainly of quartz, feldspars and lithic fragments. Finer rocks are represented by siltstones or mudstones.

Way up criteria (primarily the fining upward trend of grain size, relations of erosive/gradual transitions and the relationships of cross-lamination within beds) were used to recognize the

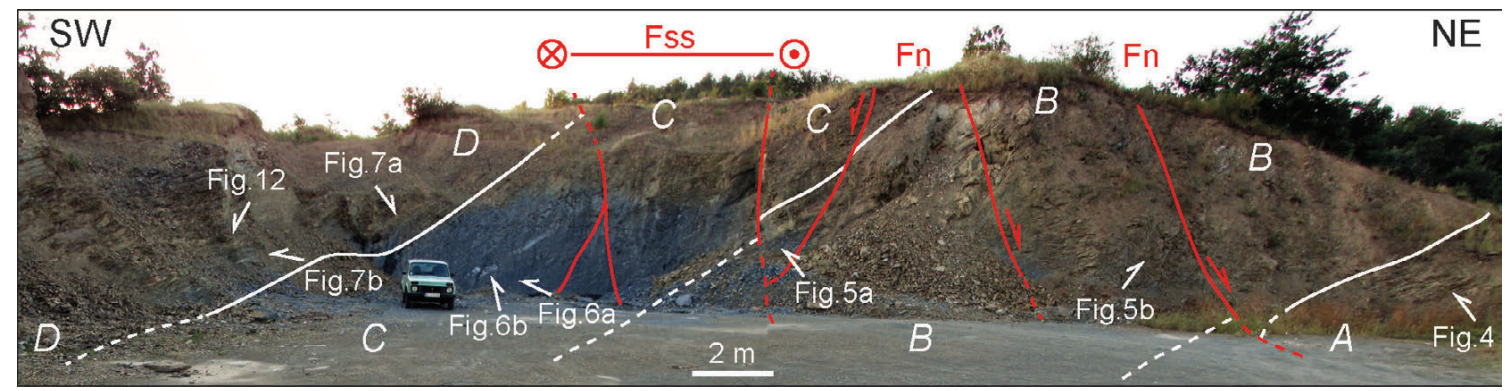

Figure 2. The siliciclastic succession in the Kostadinovica quarry. The letters $A-D$ mark the interpreted units while white lines indicate their boundaries. Fault systems (Fss - strike-slip fault zone; Fn - gravitational faults) are marked in red. White arrows point toward the position of figures presented in this paper. Photo taken during August 2019. 


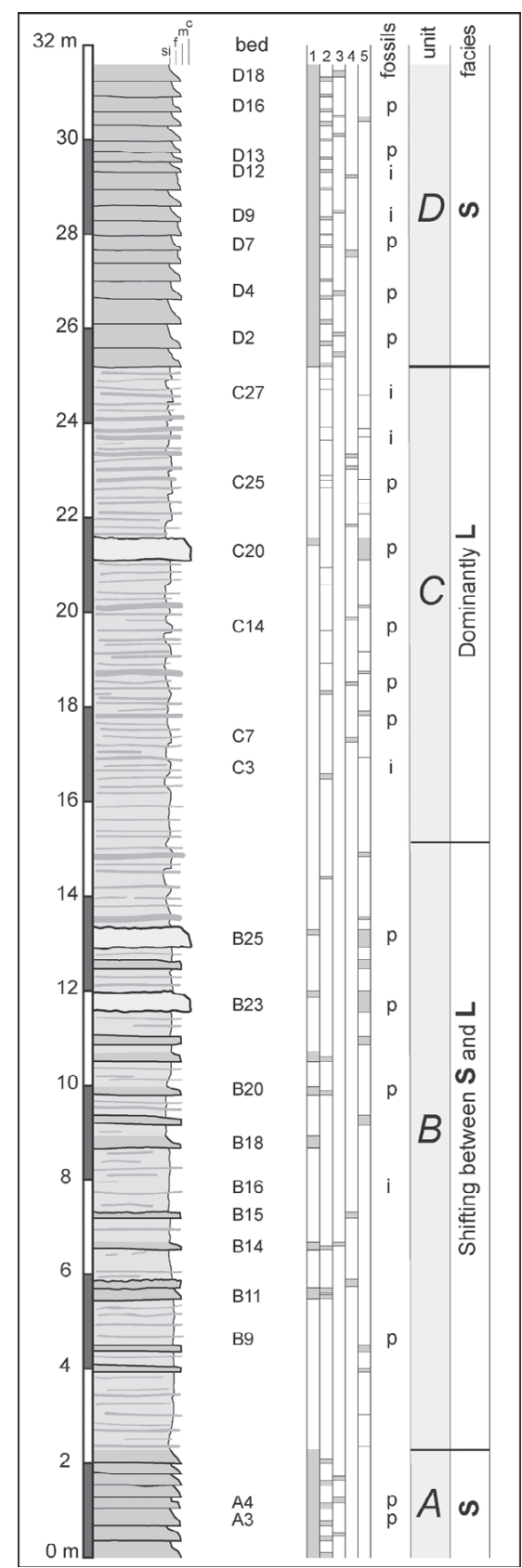

Figure 3. A sedimentological column of the Kostadinovica succession. Grain size is shown on the right-hand side of the column (si - siltstones, $\mathrm{f}$ - finegrained sandstone, $\mathrm{m}$ - medium-grained sandstone, c - coarse-grained sandstone). The sedimentary sequences or beds are designated by the letter of the unit and a number. The sedimentary structures are marked by gray boxes within corresponding columns (1 - normal grading, 2 - planar lamination, 3 - hummocky-type lamination, 4 - convolution, 5 - structureless intervals). The fossils within beds or sequences are marked by letters - $p$ (plants) and - i (ichnofossils). Interpreted units are marked by capital cursive letters A - D. All units correspond to compared facies families of the hyperpycnite tract (after ZAVALA \& PAN, 2018; see Fig. 11. for details). Facies family abbreviation: $S$ - suspended load facies; $\mathrm{L}$ - lofting facies.

stratigraphic order. The bedding monotonously dips towards the SSW (dip direction $\sim 210-235^{\circ}$ ) at an angle of 40 to $50^{\circ}$. Variations of the dip directions of bedding planes and their dip angles are due to the deformed state of the whole unit. Deformational fabrics are composed of a series of cleavages which significantly disrupt the primary sedimentary structures. Development of several orientations of cleavage planes led to unfavourable conditions for study at the outcrop (i.e. a limited potential to trace lateral continuation of bedding, brittle deformation in fine-grained

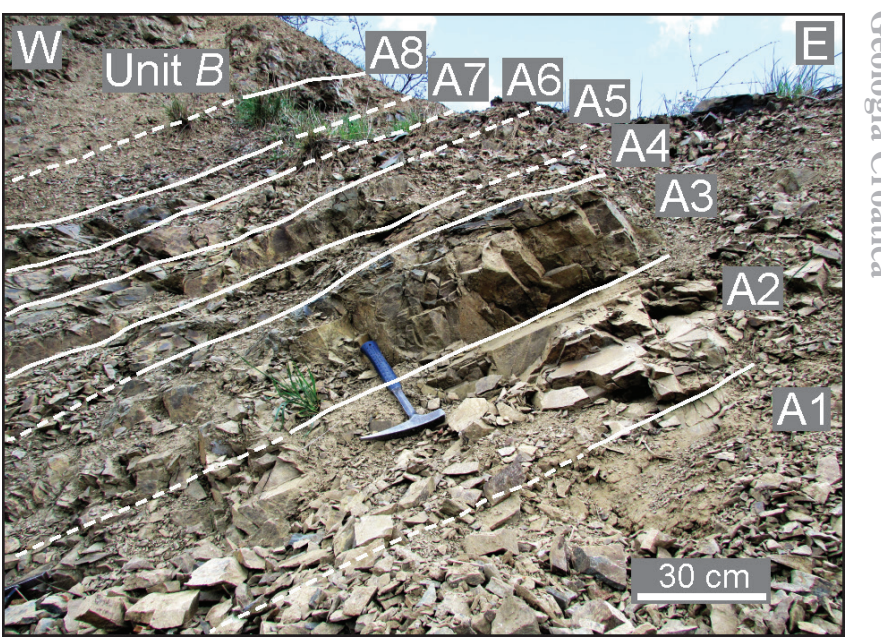

Figure 4. Sedimentary characteristics of unit $A$ of the Kostadinovica section.

rocks, etc.). Furthermore, the middle part of the succession is truncated by a system of brittle, dextral strike-slip faults (Fss in Fig. 2). Movement along these faults can be concluded based on the Riedell's plains and folding related to the faulting process. The amount of displacement along the Fss system could not be established with precision but is probably in the range of several metres and it does interrupt the superposition of the succession in its central part. The strike of several of the most prominent Fss fault planes is oriented in a NW - SE direction $\left(\sim 310-130^{\circ}\right)$ with a steep dipping angle ( $\sim 80^{\circ}$ to vertical). A second group of observed faults has a more localized influence on the succession. These faults (Fn in Fig. 2) have normal movements and are related to the Fss fault zone probably as a part of a transtensional system.

As the excavation works in the quarry progressed, different levels of the succession were exposed and studied. Based on the sedimentary characteristics, the Kostadinovica succession was subdivided into four units: $A, B, C$ and $D$ (Fig. 2). The observed sedimentological data from the section was used for the construction of a local sedimentological column (Fig. 3).

\subsection{Unit $A$ (interval: 0 to $2.10 \mathrm{~m}$ of the column)}

Stratigraphically the lowest unit $(A)$ of the succession is exposed in the NE side of the quarry and is composed of a series of normally graded turbidites (Fig. 4). Their lower parts are composed of fine- to medium-grained sandstones which pass into siltstones and have thicknesses of up to $35 \mathrm{~cm}$. The thickness of sandstone layers ranges from $\sim 5 \mathrm{~cm}$ to $\sim 20 \mathrm{~cm}$, decreasing up-section. The main internal depositional structures in the sandstone layers are parallel lamination beginning from the sharp, erosional lower surface of the bed passing into either a structureless interval or an interval with wavy lamination and then a gradual transition into siltstone (i.e. layer A3). Alternatively, layer A4 comprises of fining upward sandstone with parallel lamination which passes into a level with hummocky-like lamination with a sharp transition into siltstones. Finer-grained members make up the upper levels of sequences which are usually organized into delicate parallel lamination composed of mica grains or apparently structureless intervals.

\subsection{Unit B (interval: 2.10 to $\sim 15 \mathrm{~m}$ of the column)}

A gradual change of sedimentary characteristics occurs above the $2.10 \mathrm{~m}$ mark of the column and is represented by an increase in thickness of the siltstone intervals which comprise the lower part of unit $B$. Sedimentary structures of the finer-grained inter- 

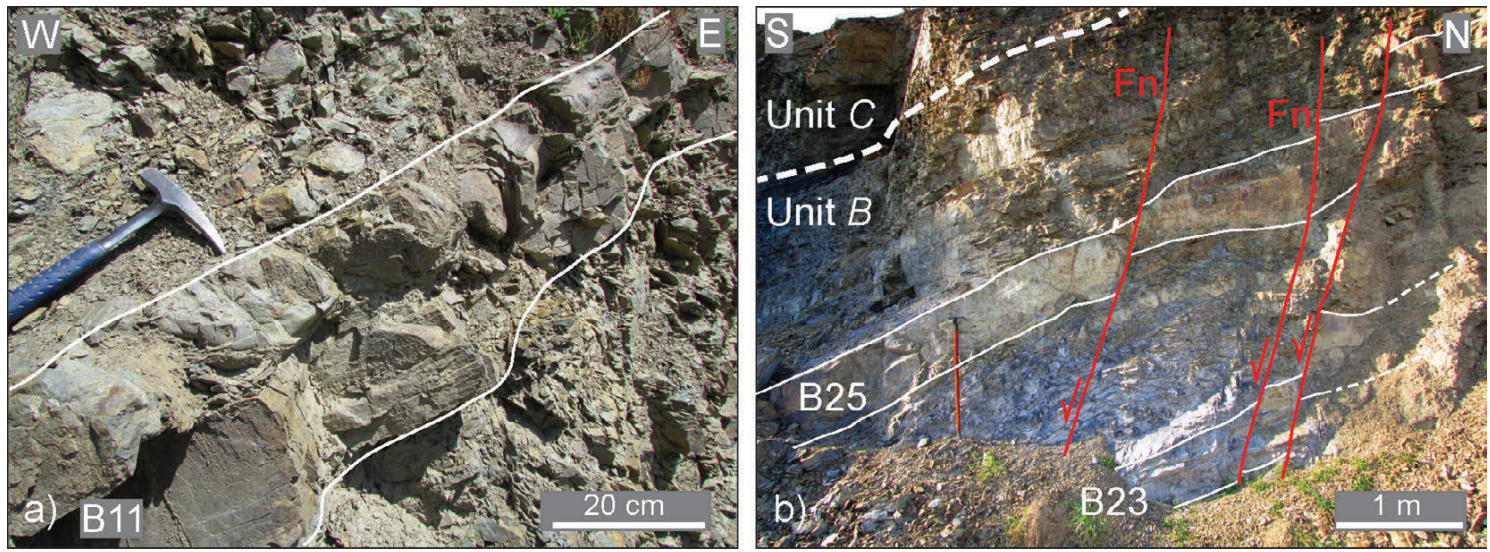

Figure 5. Sedimentary characteristics of unit $B$. (a) Fining-upward sequence B11 with convolute interval in its upper part. (b) Upper part of unit $B$ near the transition into unit $C$. Two massive sandstone beds are marked as B23 and B25 and are truncated by normal faults (Fn).

vals of this unit are obscured by cleavage, but wavy and rhythmic parallel lamination is recognized along with minute variations of grain size of the different lamina. Sandstone layers appear either as intervals of graded turbidite units or solitary structureless beds. Turbidite beds are similar in appearance to unit $A$ while structureless sandstone beds have sharp bottom and top surfaces.

Above the $4.70 \mathrm{~m}$ mark of the column a zone of fracturing (Fn) begins which disrupts the bedding for the next $6 \mathrm{~m}$ making observations at this level challenging. Nevertheless, several beds show sedimentary characteristics which could be discussed out of the superpositional context since the overall characteristics of the deformed rocks are similar to the previous level of unit $B$. Bed B11 (Fig. 5a) begins with a fining-upward sandstone with paral- lel lamination followed by a fine-grained sandstone with hummocky-type lamination. Next, a fine-grained sandstone interval shows convolute lamination. The convolute lamination appears in several other solitary beds within this level (i.e. B15). The fining upward sandstone to siltstone beds within unit $B$ occur irregularly compared to unit $A$ (beds $\mathrm{B} 18, \mathrm{~B} 20$, etc.).

The zone of fracturing fades at the about the $8 \mathrm{~m}$ mark. Above this level, two medium- to coarse-grained sandstone beds (B23 and B25) stand out compared to adjacent lithologic members (Fig.5b). Internal structures of these beds are not prominent, but a fining upward trend is noted. Faint, inclined non-parallel lamination is marked by the accumulation of coarser grains within the matrix. These beds are 50 and $40 \mathrm{~cm}$ thick, respec-
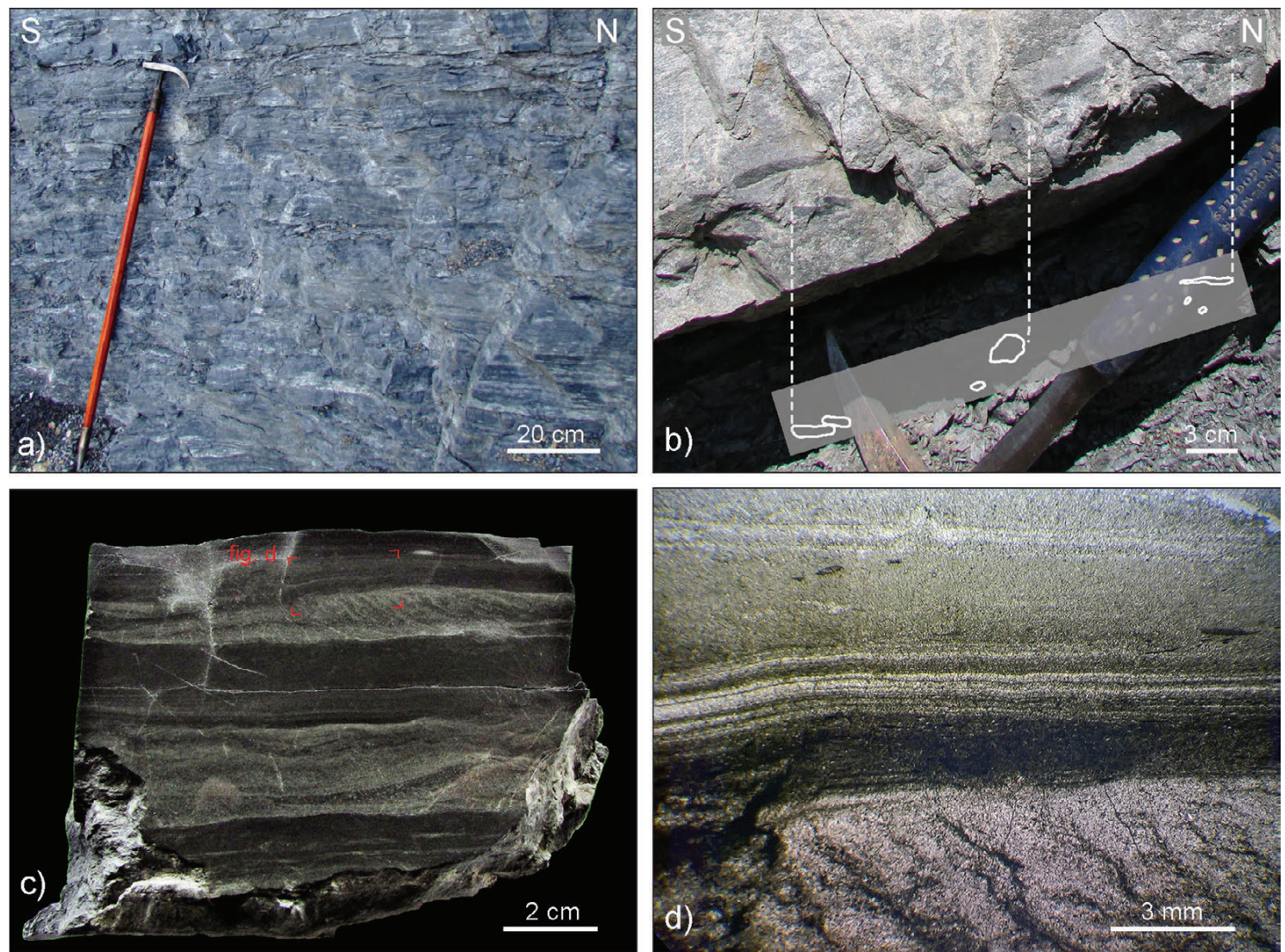

Figure 6. Sedimentary characteristics of unit C. (a) The central part of unit C showing repetition of thin siltstone and sandstone layers. Note that the white colouration on some surfaces is caused by weathering. (b) The lower part of the structureless sandstone bed C20. Clay chips are highlighted by white lines. (c) A polished rock slab showing the structures of siltstone and sandstone layers. (d) A thin-section viewed in non-polarized light showing the plant detritus above the parallel laminated siltstones. 
tively. They contain fragments of coalified plant remains of up to 1 by $5 \mathrm{~cm}$ in size which are scattered throughout the beds. Cleyey chips with diameter of $2-3 \mathrm{~cm}$ are also present. Both the lower and upper surfaces of these beds are sharp.

Beginning approximately from the $9 \mathrm{~m}$ mark of the column, a change of the colour of the rocks on a freshly broken surface is evident. The predominant colour of the lithologic members upsection is dark gray compared to the generally light brown to light gray colour of the previously described rocks. Coloration of the graded beds up to the aforementioned level is divided into brown to light brown in sandstones and olive gray to gray in fine-grained levels.

\subsection{Unit $C$ (interval: $\sim 15$ to $25.25 \mathrm{~m}$ of the column)}

Unit $C$ of the section begins above the $15 \mathrm{~m}$ mark of the column, from where there is a notable decrease in bed thickness, which on average ranges from $3-5 \mathrm{~cm}$, exceptionally up to $10 \mathrm{~cm}$. A dextral strike-slip fault zone (Fss in Fig. 2) truncates the unit at about $16 \mathrm{~m}$ and offsets the succession for several metres. Within this zone, no lateral continuity of the beds could be traced but the lithological characteristics of the rocks are similar to other levels in this unit.

Unit $C$ comprises repeating thin bedded sandstones and siltstones (Fig. 6a, c). Grading in the sandstone beds is normal or not visible while sorting of the grains is well to very well developed. Internal sedimentary structures are partially exposed in sandstones and are represented by parallel lamination and wavy lamination with a subtle transition between them. Convolute lamination intervals occur within the unit at several levels (i.e. bed C7). Structureless sandstone beds (up to $5 \mathrm{~cm}$ thick) are rare as solitary members with sharp bed boundaries. Siltstone intervals display wavy lamination marked by the accumulation of phyllosilicates (Fig. 6c, d) or they are structureless. In most cases, the structures of fine-grained rocks are discretely obscured by cleavage.

The coarse to medium-grained sandstone bed C20 is located at $21.20 \mathrm{~m}$ in the column and is distinctly different from other members of unit $C$ (Fig. 6b). This bed is $\sim 40 \mathrm{~cm}$ thick and its bottom surface is sharp with possible sole marks. The lower part of the bed appears massive while fining-upward begins in the last $\sim 10 \mathrm{~cm}$ of the bed which subtly turns into background sandstone/ siltstone couplets. Solitary cm-sized coalified plant remains are scattered throughout the bed. This bed resembles beds B20 and B23 of unit B. Dark gray, fine-grained sandstone/siltstone couplets form the next $4 \mathrm{~m}$ of unit $C$.

\subsection{Unit $D$ (interval: 25.25 to 31.75 m of the column)}

Unit $D$ begins at $25.25 \mathrm{~m}$ from the start of the column and is 6.5 $\mathrm{m}$ thick. Turbidite beds composed of medium-grained sandstones and siltstone/mudstones are the dominant members of unit $D$ (Fig. 7a). Their characteristics are similar to the turbidite beds in unit A. On average, the sandstone/siltstone sequences are 20 to $35 \mathrm{~cm}$ thick. Bottom surfaces of the sandstone intervals are sharp and often erosive on the siltstone layer of the previous bed. Internal organization of beds (i.e. D7) in this unit is usually characterized by parallel or quasi-planar lamination at the base of the mediumgrained sandstone level which turns massive upward (Fig. 7b). The next level is organized into cross-lamination or wavy lamination within fine-grained sandstones which pass gradually into structureless siltstones. Cross-lamination in the sandstone intervals varies from hummocky-type to unidirectionally inclined lamina-
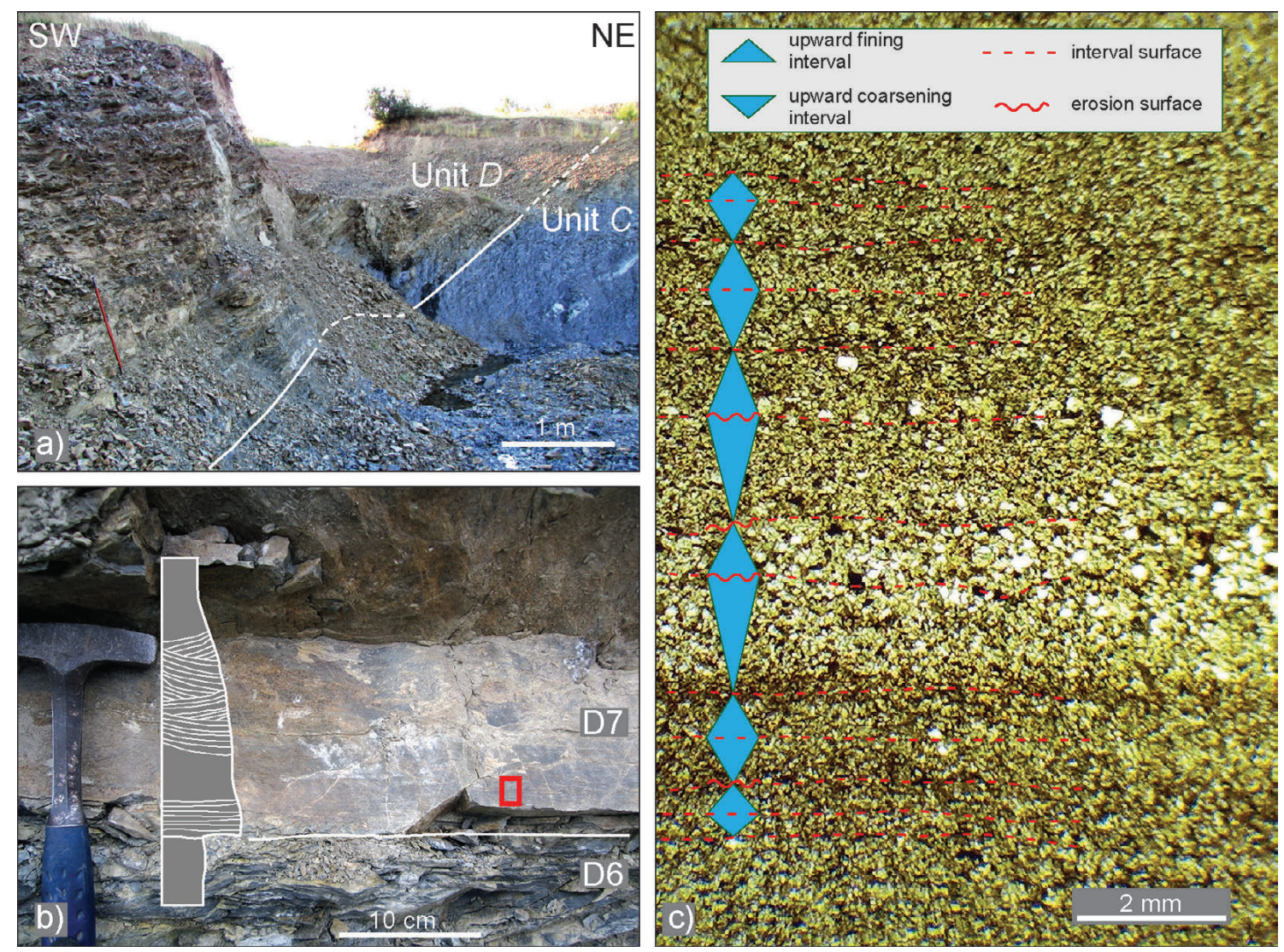

Figure 7. Sedimentary characteristics of unit $D$. (a) The transition from unit $C$ into unit $D$. The change is noticeable in the onset of fining-upward sequences (unit D) compared to sandstone/siltstone repetition (unit C). A gradual change of colour also marks the transition. (b) Internal organization of bed D7. The red rectangle is the position of the thin-section in Figure 7c. (c) Thin-section indicating repetition of upward fining and upward coarsening intervals with intrasequence erosional surfaces. View is in non-polarized light. 

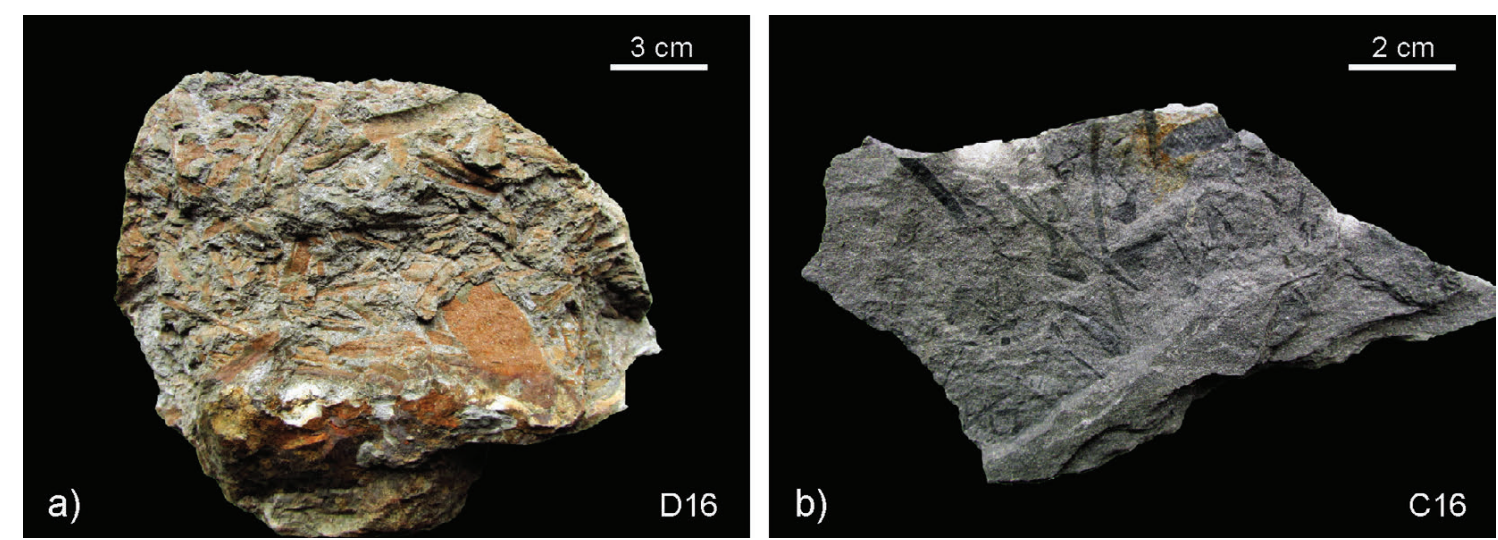

Figure 8. Typical mode of occurrence of plant detritus within the lower levels of sandstone intervals of the Kostadinovica section. (a) Plant detritus from unit $D$. Such a mode of preservation is similar within units $A$ and $B$. (b) Plant detritus from unit $C$.

tion. The siltstone levels in some cases shows delicate parallel or wavy lamination or appear without apparent structures. The parallel lamination in the lower levels of beds in unit $D$ locally contain plant detritus. In one case (bed D7), the internal structure is composed of upward coarsening and upward fining intervals sometimes separated by intrasequence erosional surfaces (Fig. 7c).

\subsection{Palaeontological material}

The Kostadinovica section contains two groups of fossil remains - abundant vascular plant debris and trace fossils. The overall deformation for both burial and the latter tectonic activity of the unit led to and accounts for the unfavourable conditions for fossilization. Overall occurrence and distribution of plant fragments and trace fossils was used as a criterion for sedimentologic and stratigraphic interpretation of the studied section and comparison with similar formations. Collected samples are stored at the Collection of Faculty of Mining and Geology, University of Belgrade (labels MRK 1-20).

\subsubsection{Vascular plants}

An important feature of the Kostadinovica section is the abundance of fragments of vascular plants. Plant detritus occurs as accumulations of delicate stem fragments scattered within the lower parts of the sandstone layers (Fig. 8). The number of accumulated fragments visible to the naked eye on a single lamina ranges from $12-\sim 80$ pieces on a surface of $10 \mathrm{~cm}^{2}$. Most often, several laminae within the same bed contain detritus accumulations. The lateral extent of the majority of the plant bearing layers could be traced to at least 5-6 m depending on circumstances within the quarry. No sorting of the fragments is observed while the orientation of the longer axis of fragments is generally chaotic. In some cases when the direction of the flow within a bed could be inferred by sedimentary structures, plant fragments show apparent directionality perpendicular to the flow. The majority of fragments show signs of intense flattening normal to the bedding surface.

Finer-grained levels in sequences at the Kostadinovica section rarely contain solitary stem fragments which are usually several centimetres long. Structureless sandstone beds also contain solitary stems and clay chips which appear randomly scattered throughout the whole bed (Fig. 6b).

The colour of the plant detritus within units $A, B$ and $D$ ranges from dark brown to pale yellow (Fig. 8a). In contrast, plant remains within unit $C$ show intensive coalification (Fig. 8b) and have a charcoal black streak. Aside from the difference in colour and level of carbonification, the mode of distribution of detritus is similar throughout the whole section.
Morphological details of plant fragments are in most cases poorly preserved which limited their more precise determination. Nevertheless, some of the specimens show characteristics of sphenopsids, pteridophylls and lycopsids (see HÜBERS et al., 2014). All the presented plant remains are comparable to the Early Carboniferous floras of the Carnic Alps (see VAN AMEROM, 1984; VAN AMEROM \& SCHÖNLAUB, 1992; VAN AMEROM \& KABON, 1999, 2000, 2003). Sphenopsids are recognized by their arrangement of vascular segments between nodes and internodes of the stems and the majority of samples belong to archeocalamiteans and sphenophylls. Among the determinable specimens Archeocalamites radiatus (BRONGNIART) STUR (Fig. 9a, b) has been identified. Less frequently, preserved fragments belonging to the sphenophylls are solitary leafless stems of Sphenophyllum tenerrimum ETTINGSHAUSEN (Fig. 9c, d). Abundant filiform foliage type detritus (MEYER-BERTHAUD \& ROWE, 1997) is grouped within the pteridophylls. Although these remains are often found throughout the Kostadinovica section, their state of preservation is often poor. Some of the preserved specimens resemble Rhodeopteridium leptofoliatum VAN AMEROM (Fig. 9e, see VAN AMEROM, 1984) or Rhodea sp. foliage types (Fig. 9f). Lycopsids are represented by stems with distinct scale marks such as Lepidodendron sp. (Fig. 9g, h).

\subsubsection{Ichnofossils}

Several turbidite beds of the Kostadinovica succession contain trace fossils belonging to the single ichnotaxon Dictyodora liebeana (GEINITZ) which show characteristics comparable to other similar occurrences (e.g. BENTON, 1982; STEPANEK \& GEYER, 1989). This is the first record of Dictyodora liebeana (GEINITZ) from the Carpatho-Balkanides of Serbia. Previous discoveries are described from the Carboniferous of the Dinarides in western Serbia (VESELINOVIĆ, 1958; KOSTIĆ et al., 1976).

The distribution and mode of appearance of Dictyodora liebeana are similar in all four units of the succession and they are located in the fine-grained layers of the turbidite beds, usually several centimetres below the erosive surface of the overlying bed. In total, 10 samples containing larger fragments of the trace fossil were collected from the Kostadinovica quarry and studied. Several other samples were studied at the quarry.

Dictyodora liebeana from the Kostadinovica section is preserved as segments of the basal burrow, traces in bedding plane view or exposed sections of the mid-dorsal vertical crest (Fig. 10). The basal burrow appears as a $7-15 \mathrm{~mm}$ wide ridge or furrow with apparent backfill (Fig.10b-d). The crest is observed on the bedding plane as meandering, 1-2 mm wide paths which are 

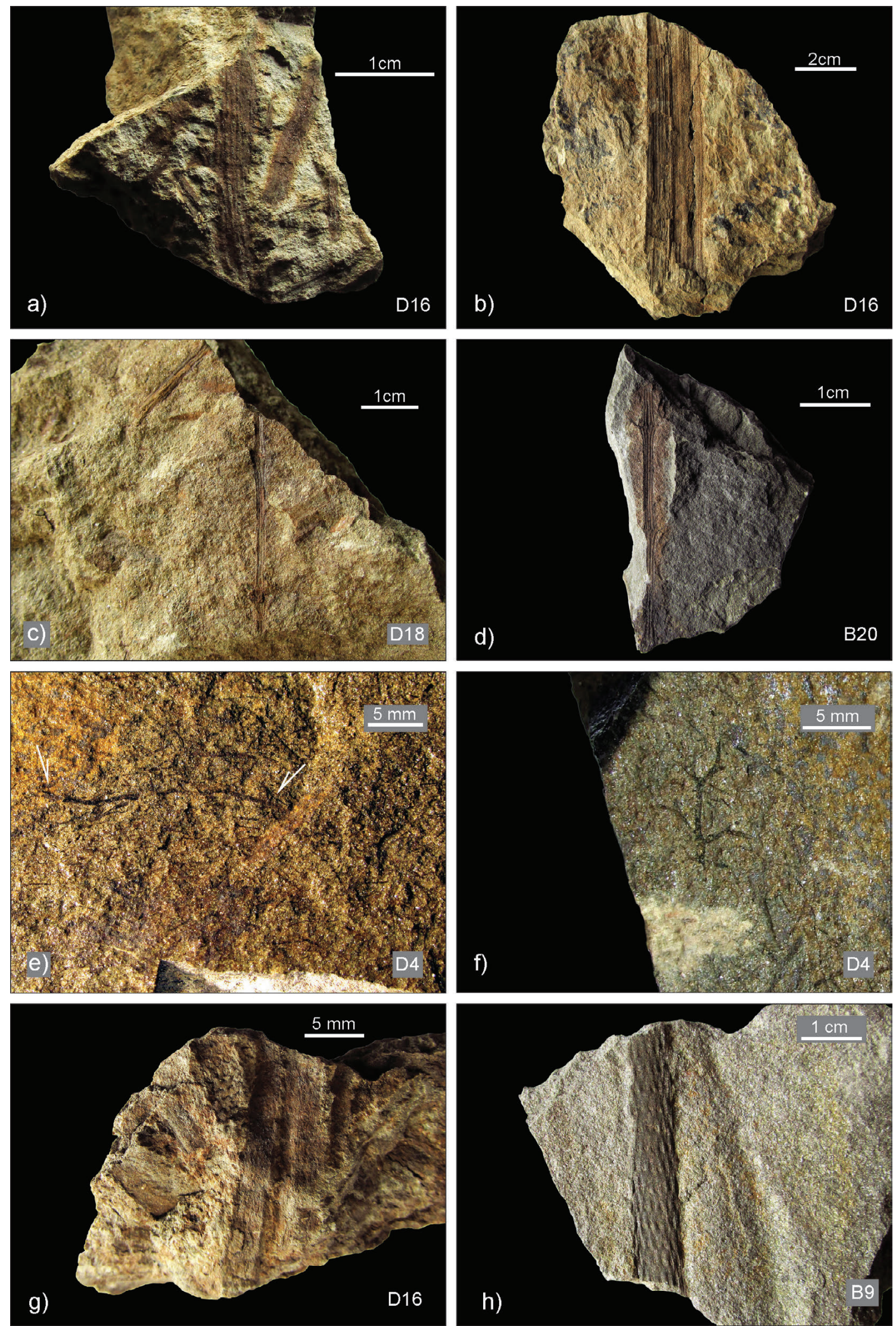

Figure 9. Plant fossils from the Kostadinovica section. Labels in the lower right corners designate their beds within the section (see Fig.3). (a) Archeocalamites radiatus (BRONGNIART) STUR. (b) Archeocalamites sp. (c, d) Sphenophyllum tenerrimum ETTINGSHAUSEN. e) Accumulation of filiform detritus and a specimen similar to Rhodeopteridium leptofoliatum VAN AMEROM (marked by white arrows). (f) Filiform Rhodea sp. type foliage. (g, h) Lepidodendron sp.

up to $20 \mathrm{~cm}$ long (Fig.10a, b). Sides of the crest show distinct oblique and longitudinal streaks produced by movement of the animal (Fig.10 c, e). Longitudinal streaks are spaced on average
$0.3-0.5 \mathrm{~mm}$ apart, while oblique streaks are arranged in rows 2-4 mm apart and run from the basal burrow upward along the crest. Due to intensive fracturing of the rocks, the trace fossil is 

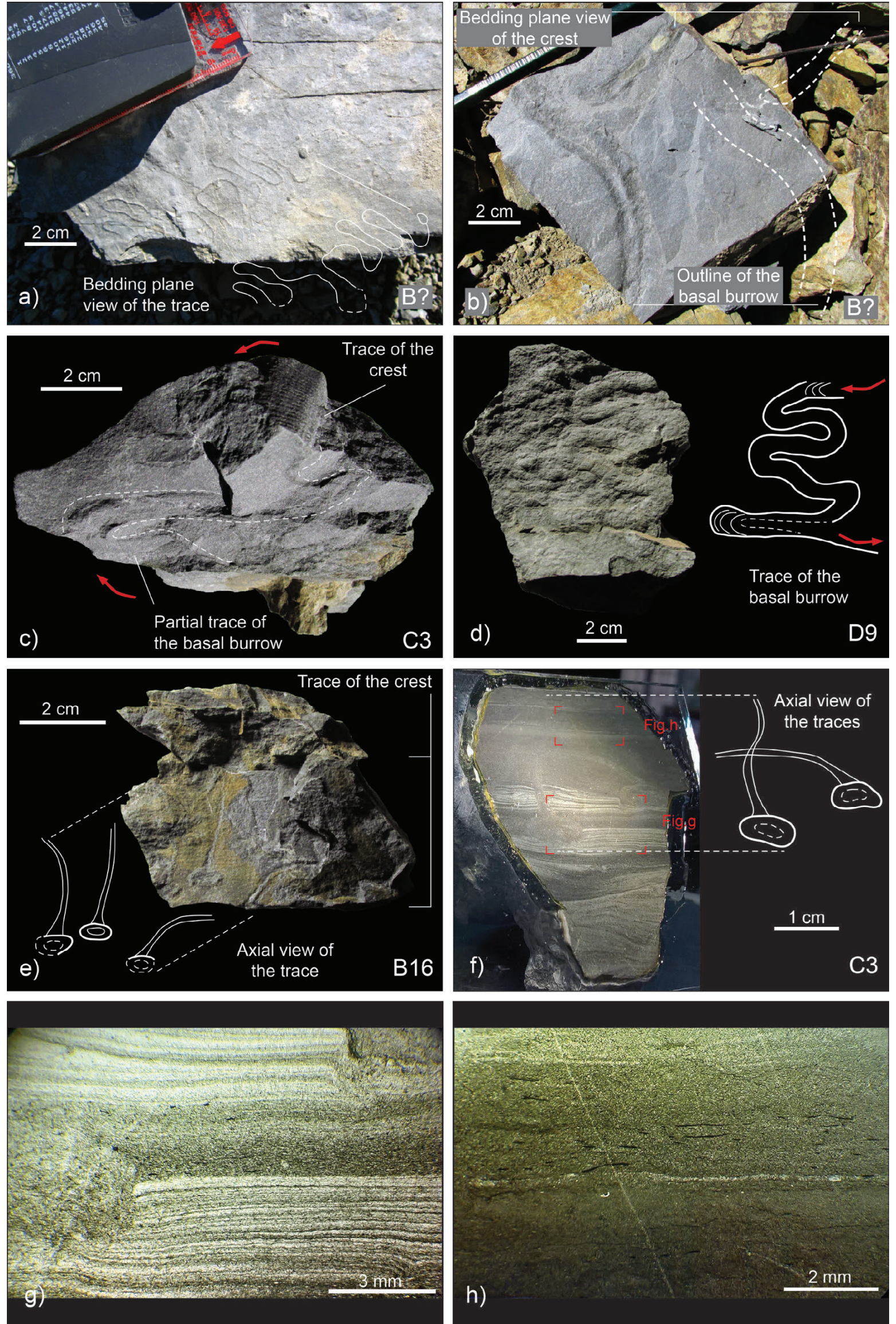

Figure 10. Various aspects of Dictyodora liebeana (GEINITZ) from the Kostadinovica section. Arrows point in the direction of the movement of the trace producing animal. Labels in the lower right corners designate their beds within the section (see Fig. 3). (a) Bedding plane view of the trace. (b) View of the basal burrow and the crest. (c) Basal burrow and the crest. (d) Lower bedding plane view of the basal burrow. (e) Axial view of the trace. (f) Polished slab showing axial view of the trace and the location of two thin-sections (Fig. $10 \mathrm{~g}, \mathrm{~h}$ ). (h) Thin-section showing the position of the traces in laminated siltstones viewed in non-polarized light. (h) Thin-section showing plant detritus in fine-grained sediment above $D$. liebeana viewed in non-polarized light. 
only partially preserved. Some of the paths show intersections, possibly from multiple individuals (Fig. 10e). The traces are located in fine-grained layers (Fig. 10f).

\section{DISCUSSION}

\subsection{The criteria for identification of hyperpycnites and their genetic model}

The sustained hyperpycnal flows which enter the basin last relatively long if the sediment-laden river discharge is sufficient to maintain the water density difference, usually for several days (MULDER \& SYVITSKI, 1995). In contrast, remobilization of the sediment by turbidity currents is manifested by brief events (lasting several minutes) that originate on the basin slope due to stability failure of the sediment (MUTTI et al., 2009). The resulting deposits of both processes reflect their different natures: (1) the hyperpycnites are composed of repetitive sedimentary sequences that contain upward coarsening intervals followed by upward fining intervals and intra-sequence erosional contacts (MULDER et al., 2003), all of which is a result of fluctuating river discharge; (2) the turbidites are represented by upward fining Bouma sequences (BOUMA, 1962) originating from a single, sediment-laden turbulent flow.
The diagnostic criterion for hyperpycnites is the internal organization of the sedimentary sequence consisting of couplets of inverse and normally graded layers with intersequence erosional surfaces (MULDER et al., 2003; YANG et al., 2017). Given that the Kostadinovica section is composed of fine-grained rocks which could be considered to belong to the distal part of the turbidite system (Fig. 3., KRSTIĆ, 1984), the minute variations in grain size and structure would be best observed in thin-section. Out of the dozen rock samples collected, only one thin-section (sample from bed D7, Fig. 7c) fulfills the diagnostic criterion for hyperpycnites. The similarity of macroscopic sedimentary characteristics of several layers containing plant detritus and bed D7 could be potentially used to indicate their hyperpycnal origin. In addition to sedimentological data, collected fossil material from the site was discussed as an argument for a hyperpycnal mode of transport of the sediment.

The siliciclastic succession at Kostadinovica shows sedimentary and palaeontological characteristics which could be compared to the model of extrabasinal turbidites (ZAVALA \& ARCURI, 2016). The observed rocks at the Kostadinovica site were grouped into different facies and further discussed following the proposed genetic model of facies for hyperpycnites (Fig.11; ZA-

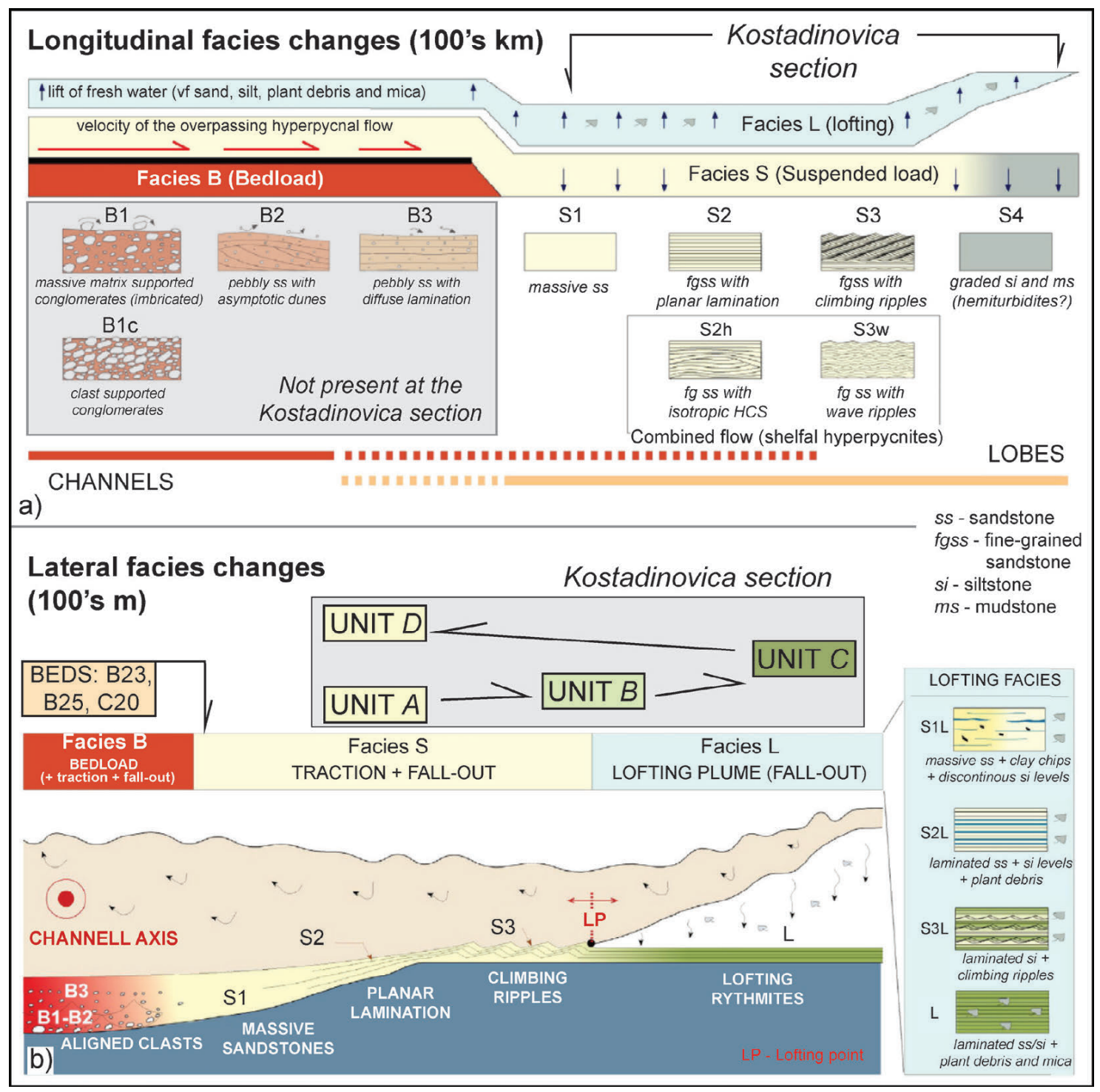

Figure 11. The proposed genetic facies model used on the Kostadinovica section (modified after ZAVALA \& ARCURI, 2016). (a) Longitudinal changes of characteristics of facies. (b) Lateral changes of characteristics of facies. 
VALA \& PAN, 2018). In the mentioned genetic model (ZAVALA \& ARCURI, 2016), facies families are related to the main processes governing deposition from the sustained hyperpycnal discharge: (1) deposition of coarse-grained material which is dragged by turbulent flow on the bottom of the current (bedload - facies B), (2) deposition of the sediment suspended in the flow during its deceleration (suspended load - facies S) and (3) deposition of fine-grained sediment under the density reversal of the hyperpycnal flow when its flow capacity decreases (lofting load - facies L). Each facies family is further subdivided by its specific characteristics (Fig. 11).

\subsection{Comparison of the Kostadinovica section to the proposed genetic model}

Units $A$ and $D$ of the Kostadinovica section are characterized by fining-upward sequences which would correspond in most cases to the suspended load facies (S) family and transitional domains of the lofting facies (L) family (Fig. 11, ZAVALA \& PAN, 2018). The sandstone layers within these units mostly represent facies S2L (sandstone with parallel lamination and plant debris), S2h (sandstone with hummocky-type cross lamination) or S3w (sandstone with wavy lamination). The upper, fine-grained part of the beds would correspond to facies S4 (graded siltstones and mudstones) or in some cases the possible background deposition of pelagic sediments. Compared to the proposed model (ZAVALA \& PAN, 2018), the observed vertical association of different facies within units $A$ and $D$ is interpreted as a series of hyperpycnites deposited in a relatively regular order based on the fossil material and sedimentological characteristics.

Unit $B$ shows the greatest variety of proposed hyperpycnal facies and their irregular transition from one to another. Lower levels of the unit comprise mostly of siltstones and mudstones of facies S4. Structureless sandstone beds represent solitary events of deposition of facies $\mathrm{S} 1$ (massive sandstones). The nature of two prominent beds - B23 and B25, could correspond to the characteristics of facies S1L (massive sandstones with clay chips, silt levels and plant debris) or alternatively facies B3 (pebbly sandstones with diffuse lamination) and reflect events of higher intensity within a relatively calm environment.

Unit $C$ is predominantly composed of members of the lofting facies family L (laminated sandstones and siltstones with plant debris). The more fine-grained members of the unit are rarely disturbed by thin, structureless sandstone beds of facies S1. The intervals of sandstone beds with irregular wavy lamination represent deposition under a combined flow (facies S3w). According to the proposed model (ZAVALA \& PAN, 2018), unit $C$ is deposited in conditions of density reversal of a hyperpycnal flow due to its reduction caused by ongoing sedimentation which leads to deposition of fine-grain particles and more buoyant plant debris (GLADSTONE \& PRITCHARD, 2010). This lofting process takes place in the marginal parts of the system (outward of the lofting point - LP, Fig. 11b).

The onset of unit $D$ is marked by a sharp change in facies association compared to unit $C$. Aside from the general similarities described above, differences within units $A$ and $D$ are most notably the rare occurrence of $\mathrm{S} 3$ facies (fine-grained sandstones with climbing ripples) within unit $D$.

In terms of the lateral geometry of the proposed system at the Kostadinovica section, the change to more fine-grained lithologies should mark the shift away from the central zone of superimposed channel axes towards lobes of the system (from unit $A$ towards unit $C$ ), while the opposite shift would mark migration back towards the centre of the system (unit $D$ ) (Fig. 11b). The alternative interpretation would consider a change in energies of the events within units or at least the combination of both parameters. The vertical organization of facies within the succession is in accordance with expected facies changes (i.e. vertical transition from facies S2 to S3 to S4 and intermediate domains; see Fig. 11a). This is best observed within units $A$ and $D$ while in other cases this could be explained by invoking the influence of various deep-marine processes.

\subsection{Interpretation of the fossil association}

The most prominent feature of the Kostadinovica section is the fossil association of terrestrial vascular plants and the trace fossil Dictyodora liebeana (GEINITZ). These fossils were used to determine the age of the succession and to better constrain its sedimentary setting.

Remains of vascular plants from the studied section show characteristics which could be compared to Mississippian floras of the Variscides of central and western Europe (HÜBERS et al., 2014). The presented association of sphenophytes, lycophytes and filiform foliage (Fig. 9) indicates a Viséan to Serphukovian age for the Kostadinovica succession based on similar material from other European localities, of which some examples are from Lower Silesia (Poland, ZIMMERMANN, 1956), Doberlug-Kirchhain (Germany, DABER, 1959), Giromagny (France, CORSIN et al., 1973), Hochwipfel flysch of the Carnic Alps (Austria and Italy, VAN AMEROM et al., 1984; VAN AMEROM \& SCHÖLAUB, 1992, VAN AMEROM \& KABON, 1999, 2000, 2003) and the eastern Pyrenees (Spain, MARTÍN-CLOSAS et al., 2018). A factor common to the aforementioned occurrences and the Kostadinovica section is the transport of the plant material under the turbiditic flow regime. The presented samples from the Kostadinovica site are the first discoveries of the Early Carboniferous flora from Serbia. Previous palaeobotanical studies attributed the remains of the macroflora from the Carpatho-Balkanides either to the Devonian or Late Carboniferous exclusively (PANTIĆ, 1960; KRSTIĆ, 2005; see ĐORĐEVIĆ-MILUTINOVIĆ, 2010).

Another significant palaeontological feature of the Kostadinovica section is the trace fossil (Fig. 10) Dictyodora liebeana (GEINITZ) which is interpreted as a post-depositional deep-tier pascichnion found in Mississippian deep-sea environments (e.g. SEILACHER, 2007; CALLOW \& MCILROY, 2011; UCHMAN \& WETZEL, 2011). Its occurrences are often described from the Culm facies, e.g. in Thuringia (Germany, BENTON, 1982 and references therein), Frankenwald (Germany, STPANEK \& GEYER, 1989), Menorca (Balearic Islands, ORR, 1994; ORR \& BENTON, 1996), Moravia and Silesia (Czech Republic, BÁBEK et al., 2004; MIKULÁŠ et al., 2002, 2004; KOVÁČEK \& LEHOTSKÝ, 2016; Poland, MUSZER, 2020), Carnic Alps (Austria and Italy, BAUCON \& NETO DE CARVALHO, 2008). The stratigraphic range of Dictyodora liebeana (GEINITZ) is confined to the Early Carboniferous (UCHMAN, 2004).

One of the arguments for the presence of hyperpycnites within the turbidites deposited in a deep marine environment at the Kostadinovica succession is the occurrence of the post-turbidite pascichnion Dictyodora liebeana (GEINITZ) in the upper, fine-grained intervals of the turbidites followed by plant debris accumulations on lamination surfaces within the bottom, coarsegrained levels of the next bed (beds D12 and D13, Fig. 12;). The presence of Dictyodora liebeana (GEINITZ) in proximity to vascular plant debris is observed in several intervals of units $B, C$ (bed C3, fig. 10f-h) and D. Such distribution of the trace fossils 


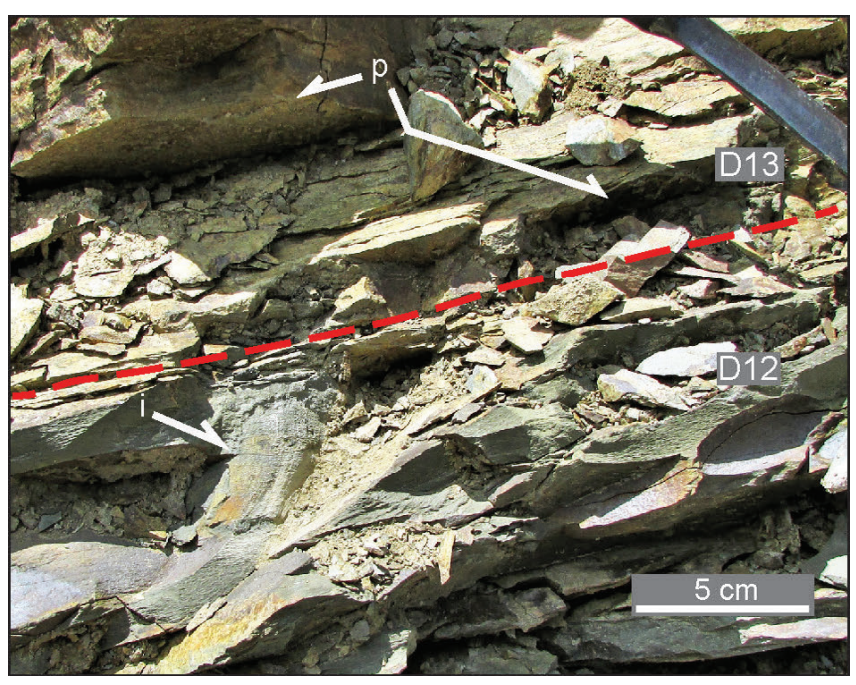

Figure 12. The fossil association as an argument for hyperpycnal influence within the turbiditic succession at Kostadinovica. The bed D12 contains Dictyodora liebeana (GEINITZ) (i) in its siltstone interval. The crest is exposed showing its characteristic longitudinal and oblique streaks. The next bed (D13) contains plant debris $(p)$ within the basal sandstone layer with parallel lamination.

and plants could indicate repetitive hyperpycnal events triggering (or coinciding with) turbiditic transport of the sediment representing several dozen events reflected as distinct sequences (at least within units $A$ and $D$ ).

\section{CONCLUSIONS}

The siliciclastic succession at Kostadinovica, as part of the Kučaj-Zvonce flysch (KRSTIĆ \& MASLAREVIĆ, 1989), is interpreted here as representing the distal part of a turbiditic system with the occasional occurrence of hyperpycnites. The main arguments for the validity of the proposed model are sedimentary characteristics corresponding to the model of extrabasinal turbidites (ZAVALA \& PAN, 2018) and the concurrent fossil association of in situ deep-marine ichnofossils and debris of vascular plants transported by hyperpycnal currents (ZAVALA et al., 2012). The identification of hyperpycnites by thin-section analyses is only partially achieved and further studies are needed for their more precise discrimination from turbidites. Likewise, more detailed study of the petrographic and geochemical provenance of the material would benefit research on a palaeontologically controlled succession as in the one at the Kostadinovica site (see KUTTEROLF et al., 2008).

Based on the discovery of Dictyodora liebeana (GEINITZ) the age of the studied section is established as Early Carboniferous instead of Devonian (KRSTIĆ, 1984) which is in accordance with the characteristics of the associated Mississippian vascular plants (HÜBERS et al., 2014). A more detailed age range could be defined as Viséan to Middle Serpukhovian if compared to the Hochwipfel flysch (HUBMANN et al., 2014). These results could have age implications for similar described occurrences of the Kučaj-Zvonce flysch of the Carpatho-Balkanides of Serbia (KRSTIĆ et al., 2004; KRSTIĆ et al., 2005).

Palaeontologically controlled successions such as the Kostadinovica section offer an important insight into the direct link of continental environments and deep-marine realms. Further studies could provide more information on palaeoenvironmental conditions and sedimentary systems of the studied Kučaj-Zvonce flysch and similar depositional settings (see SREMAC, 2012; FAN \& GONG, 2016). Contemporaneous equivalent formations within adjacent regions (e.g. the Hochwipfel flysch of the Carnic Alps and the South Karavanke, Lower Carboniferous of the Dinarides, Sredna Gora in Bulgaria) could be better compared based on floral elements and their similar sedimentological characteristics.

\section{ACKNOWLEDGEMENT}

I thank Tom van LOON and Alfred UCHMAN for offering important and helpful comments. Ljupko RUNDIĆ, Dejan RADIVOJEVIĆ, Nevenka ĐERIĆ and Hans-Jürgen GAWLICK are gratefully acknowledged for their support and encouragement of this work.

\section{REFERENCES}

BÁBEK, O., MIKUÁŠ, R., ZAPLETAL, J. \& LEHOTSKÝ, T. (2004): Combined tectonic-sediment supply-driven cycles in a Lower Carboniferous deep-marine foreland basin, Moravice Formation, Czech Republic.- Int. J. Earth Sci., 93/2, 241-261. doi: 10.1007/s00531-004-0388-5

BAUCON, A. \& NETO DE CARVALHO, C. (2008): From the river to the sea: Pramollo, a new ichnolagerstätte from the Carnic Alps (Carboniferous, Italy-Austria).Acta Geol., 83, 87-114.

BENTON, M.J. (1982): Dictyodora and associated trace fossils from the Paleozoic of Thuringia.- Lethaia, 15, 115-132.

BOUMA, A.H. (1962): Sedimentology of some Flysch Deposits. A Graphic Approach to Facies Interpretation. Elsevier, Amsterdam, $168 \mathrm{p}$.

CALLOW, R.H.T. \& MCILROY, D. (2011): Ichnofabrics and ichnofabric-forming trace fossils in Phanerozoic turbidites.- Bulletin of Canadian Petroleum Geology, 59/2, 103-111. doi: 10.2113/gscpgbull.59.2.103

CORSIN, P., COULON, M., FOURQUIN, C., PAICHELER, J.C. \& POINT, R. (1973): Etude de la flore de la série de Giromagny (Viséen Supérieur des Vosges méridionales). Comparaison avec les autres flores du Culm des Vosges.- Bulletin Sciences Géologiques, 26/1, 43-68. doi: 10.3406/sgeol.1973.1425

DABER, R. (1959): Die Mittel-Visé-Flora der Tiefbohrungen von Doberlug-Kirchhain.Geologie, 8/26, 1-83. Berlin.

DIMITRIJEVIĆ, M.D. (1997): Geology of Yugoslavia.- Geological Institute GEMINI, Special Publication, 187 p., Belgrade.

ĐORĐEVIĆ-MILUTINOVIĆ, D. (2010): An overview of Paleozoic and Mesozoic sites with macroflora in Serbia.- Bulletin of the Natural History Museum, 3, 27-46. Belgrade.

EBNER, F., VOZÁROVÁ, A., KOVÁCS, S., KRÄUTNER, H., KRSTIĆ, B., SZEDERKÉNYI, T., JAMIČIĆ, D., BALEN, D., BELAK, M. \& TRAJANOVA, M. (2008): Devonian-Carboniferous pre-flysch and flysch environments in the Circum Pannonian Region.- Geologica Carpathica, 59/2, 159-195.

GEINITZ, H.B. (1867): Die organischen Überreste im Dachschiefer von Würzbach bei Löbenstein. [The organic leftovers in Dachschiefer formation from Würzbach bei Löbenstein - in German].- Nova Acta Acad. Caes. Leop. Carol., German. Natur. Curios., 33/3, 1-24.

GLADSTONE, C. \& PRITCHARD, D. (2010): Patterns of deposition from experimental turbidity currents with reversing buoyancy.- Sedimentology, 57, 53-84. doi: 10.1111/j.1365-3091.2009.01087.x

FAN, R.Y. \& GONG, Y.M. (2016): Ichnological constraints of palaeoenvironmental and palaeoclimatological features of the middle Palaeozoic Palaeo-Asian Ocean, evidence from the western Junggar, NW China.- Palaeogeography, Palaeoclimatology, Palaeoecology, 459, 209-228. doi: 10.1016/j.palaeo.2016.07.012

HÜBERS, M., BOMFLEUR, B., KRINGS, M., POTT, C. \& KERP, H. (2014): A reappraisal of Mississippian (Tournaisian and Visean) adpression floras from central and northwestern Europe.-Zitteliana A, 54, 39-52. doi: 10.5282/ubm/epub.22322

HUBMANN, B., EBNER, F., FERRETTI, A., KIDO, E., KRAINER, K., NEUBAUER, F., SCHÖNLAUB, H.-P. \& SUTTNER, T.J. (2014): The Paleozoic Era(them), $2^{\text {nd }}$ edition.- In: PILLER, W.E. [ed.]: The lithostratigraphic units of the Austrian Stratigraphic Chart 2004 (sedimentary successions), Vol. I. Abhandlungen der Geologischen Bundesanstalt, 66, 9-133, Wien.

KOSTIĆ, V., PEŠIĆ, L. \& FILIPOVIĆ, I. (1976): Fosilni tragovi („,bioglif“) iz Karbonskih tvorevina zapadne Srbije i njihov značaj [Trace fossils from Carboniferous of western Serbia and their importance - in Serbian with an English summery].-Ann. Geol. Pennins. Balk., 40, 127-135.

KOVÁČEK, M. \& LEHOTSKÝ, T. (2016): Ichnofosilie Myslejovického Souvrství Drahanského Kulmu (Spodní Karbon, Moravskoslezská Jednotka Českého Masivu). [Trace fossils from the Myslejovice Formation of the Drahany Culm Basin (Lower Carboniferous, Moravosilesian unit of the Bohemian Massif) - In Chech, with an English abstract].--Geologické výzkumy na Moravě a ve Slezsku v roce 2016, $24-41$.

KRÄUTNER, H.G. \& KRSTIĆ, B. (2002): Alpine and Pre-Alpine structural units within the Southern Carpathians and the Eastern Balkanides.- Proceedings of XVII Congress of Carpathian-Balkan Geological Association, Bratislava, September 1-4, 2002. Geologica Carpatica, Special Issue 53. 
KRÄUTNER, H.G. \& KRSTIĆ, B. (2003): Geological map of the Carpatho-Balkanides between Mehadia, Oraviţa, Niš and Sofia.- Geoinstitute Gemini, Belgrade.

KRSTEKANIĆ, N., STOJADINOVIĆ, U., KOSTIĆ, B. \& TOLJIĆ, M. (2017): Internal structure of the Supragetic Unit basement in the Serbian Carpathians and its significance for the late Early Cretaceous nappe-stacking.- Ann. Geol. Pennins. Balk., 78, 1-15. doi: 10.2298/GABP1778001K

KRSTIĆ, B. (1984): Stratigrafija starijeg paleozoika (ordovicijum-devon) između Resave i Nišave, istočna Srbija. [Stratigraphy of the Lower Paleozoic (Ordovician-Devonian) between rivers Resava and Nišava - eastern Serbia - in Serbian, with an English summary].- Mémoires du Service Geologique et Geophisique, 22, 1-64. Belgrade.

KRSTIĆ, B. \& SUDAR, M. (1989): Paleozojski konodonti istočne Srbije, Jugoslavija - I. Konodonti franskog kata iz okoline Zvonačke banje [Paleozoic Conodonts of eastern Serbia, Yugoslavia - I. Conodonts of Frasnian stage from Zvonačka banja area - in Serbian, with an English abstract].- Ann. Geol. Pennins. Balk., 53, 305-318.

KRSTIĆ, B. \& MASLAREVIĆ, LJ. (1990): Depositional environment of the marine Palozoic in the Hercynid Kučaj zone, eastern Serbia.- Bulletin T. CII de l'Académie serbe des sciences et des arts - Classe des sciences mathématiques et naturelles, Sciences Naturelles, 32, 29-37. Belgrade.

KRSTIĆ, B., MASLAREVIĆ, LJ., ERCEGOVAC, M., SUDAR, M. \& ĐAJIĆ, S. (2004): Devonian in the Carpatho-Balkanides of Eastern Serbia.- Bulletin T. CXXVIII de l'Académie serbe des sciences et des arts - Classe des sciences mathématiques et naturelles, Sciences Naturelles, 42, 7-16. Belgrade.

KRSTIĆ, B., FILIPOVIĆ, I., MASLAREVIĆ, LJ., SUDAR, M. \& ERCEGOVAC, M. (2005): Carboniferous of the Central Part of the Balkan Peninsula.- Bulletin T. CXXX de l'Académie serbe des sciences et des arts - Classe des sciences mathématiques et naturelles, Sciences Naturelles, 43, 9-28. Belgrade.

KRSTIĆ, B., MASLAREVIĆ, LJ., SUDAR, M. \& ERCEGOVAC, M. (2008): Paleozoic and Lower Triassic Formations in the SE part of the East Serbian Carpatho-Balkanides.- Bulletin T. CXXXV de l'Académie serbe des sciences et des arts - Classe des sciences mathématiques et naturelles, Sciences Naturelles, 44, 41-56. Belgrade.

KUTTEROLF, S., RÜDIGER, D., SCHACHT, U. \& KRAWINKEL, H. (2008): Provenance of the Carboniferous Hochwipfel Formation (Karawanken Mountains, Austria/ Slovenia) - Geochemistry versus petrography.-Sedimentary Geology, 203, 246-266. doi: 10.1016/j.sedgeo.2007.12.004

MARTÍN-CLOSAS, C., TRIAS, S. \& CASAS, J.M. (2018): New palaeobotanical data from Carboniferous Culm deposits constrain the age of the Variscan deformation in the eastern Pyrenees.- Geologica Acta, 16/2, 107-123. doi: 10.1344/GeologicaActa2018.16.2.1

MASLAREVIĆ, LJ. \& KRSTIĆ, B. (1987a): The Kučaj-Zvonce Flysch.- In: DIMITRIJEVIĆ, M.N. \& DIMITRIJEVIĆ, M.D. (eds.): The Turbiditic Basins of Serbia. Serbian Academy of Sciences and Arts Monographs, 61, 211-237, Belgrade.

MASLAREVIĆ, LJ. \& KRSTIĆ, B. (1987b): Paleozojske olistostrome u kučajskozvonačkom flišu jugoslovenskog dela Karpato-Balkanida [Paleozoic Olistostromes in the Kučaj-Zvonce Flysch of the Yugoslavian Carpathio-Balkanides - in SerboCroatian with an English summery].- Geol. vjesnik, 44, 217-232, Zagreb.

MEYER-BERTHAUD, B. \& ROWE, N.P. (1997): A Lower Carboniferous plant assemblage from Thuringia (Germany): compressions.- Review of Paleobotany and Palynology, 97, 361-379. doi: 10.1016/S0034-6667(96)00075-9

MIKULÁŠ, R., LEHOTSKÝ, T. \& BÁBEK, O. (2002): Ichnofabric of the Culm facies: a case study of the Moravice Formation (Lower Carboniferous; Moravia and Silesia, Czech Republic).- Geol. Carpathica, 53, 141-148.

MIKULÁŠ, R., LEHOTSKÝ, T. \& BÁBEK, O. (2004): Trace fossils of the Moravice Formation from the southern Nízký Jeseník Mts. (Lower Carboniferous, Culm facies; Moravia, Czech Republic).- Bulletin of Geosciences, 79/2, 81-98.

MULDER, T. \& SYVITSKI, J.P.M. (1995): Turbidity Currents Generated at River Mouths during Exceptional Discharges to the World Oceans.- Journal of Geology, 103, 285-299. doi: 10.1086/629747

MULDER, T., SYVITSKI, J.P.M., MIGEON, S., FAUGĖRES, J.-C. \& SAVOY, B. (2003): Marine hyperpycnal flows: initiation, behavior and related deposits. A review.- Marine and Petroleum Geology, 20, 861-882. doi: 10.1016/j.marpetgeo.2003.01.003

MUSZER, J. (2020): trace fossils from the Mississippian of the Piaskowa Góra section (the Intra-Sudetic Basin, SW Poland).--Annales Societatis Geologorum Poloniae, 90, doi: 10.14241/asgp.2020.06

MUTTI, E., BERNOULLI, D., RICCI LUCCI, F. \& TINTERRI, R. (2009): Turbidites and turbidity currents from Alpine 'flysch' to the exploration of continental margins.Sedimentology, 56, 267-318. doi: 10.1111/j.1365-3091.2008.01019.x

ORR, P. (1994): Trace fossil tiering within event beds and preservation of frozen profiles: An example from the Lower Carboniferous of Menorca.-Palaios, 9/2, 202-210. doi: $10.2307 / 3515106$

ORR, P.J. \& BENTON, J.M. (1996): Deep marine trace fossil assemblages from the Lower Carboniferous of Menorca, Balearic Islands, western Mediterranean.--Geological
Journal, 1, 235-258. doi: 10.1002/(SICI)1099-1034(199609)31:3\%3C235::AIDGJ706\%3E3.0.CO;2-4

PANTIĆ, N. (1960): Devonska flora istočne Srbije. [Devonian flora of eastern Serbia - in Serbian, with an German abstract].- Ann. Geol. Pennins. Balk., 27, 296-315.

SCHMID, M.S., FÜGENSCHUH, B., KUNOV, A., MATENCO, L., NIVERGELT, P., OBERHÄNSLI, R., PLEUGER, J., SCHEFER, S., SCHUSTER, R., TOMLJENOVIĆ, USTASZEWSKI, K. \& VAN HINSBERGEN, D.J.J. (2020): Tectonic units of the Alpine collision zone between Eastern Alps and western Turkey.Gondwana Research, 78, 308-374. doi: 10.1016/j.gr.2019.07.005

SEILACHER, A. (2007): Trace Fossil Analysis.- Springer-Verlag Berlin, 236 p.

SREMAC, J. (2012): Influence of terrestrial sedimentation in Pennsylvanian rocks of Croatia.- Geologia Croatica, 65/3, 273-282. doi: 104154/gc.2012.18

STOW, D.A.V. (2005): Sedimentary Rocks in the Field: A Colour Guide.- Manson Publishing Ltd., London, 205 p. doi: 10.1201/b15204

STPANEK, J. \& GEYER, G. (1989): Spurenfossilien aus dem Kulm (Unterkarbon) des Frankenwaldes.- Beringeria, 1, 1-55.

UCHMAN, A. (2004): Phanerozoic history of deep-sea trace fossils.- In: MCILROY, D. (ed.): The Application of Ichnology to Palaeoenvironmental and Stratigraphic Analysis.-Geological Society London, Special Publications, 228, 125-139. doi: 10.1144/ GSL.SP.2004.228.01.07

UCHMAN, A. \& WETZEL, A. (2011): Deep-sea ichnology: The relationships between depositional environment and endobenthic organisms.- In: HÜNEKE, H. \& MULDER, T. (eds.): Deep-sea sediments. Developments in Sedimentology, 63, 517-556. doi: 10.1016/B978-0-444-53000-4.00008-1

VAN AMEROM, H.W.J., FLAJS, G. \& HUNGER, G. (1984): Die "Flora der MarinelliHütte" (mittleres Visé) aus dem Hochwipfel Flysch der Karnischen Alpen (Italien).Mededelingen Rijks Geologische Dienst, 37/3, 21-61, Heerlen.

VAN AMEROM, H.W.J. \& SCHÖNLAUB, H.P. (1992): Pflanzenfossilien aus dem Karbon von Nötsch und der Hochwipfel-Formation der Karnischen Alpen (Österreich).Jb. Geol. B.-A., 135/1, 195-216, Wien.

VAN AMEROM, H.W.J. \& KABON, H. (1999): Neue fossile Floren aus dem Nötscher Karbon (1. Teil).- Carinthia II, 189/109, 637-672, Klagenfurt.

VAN AMEROM, H.W.J. \& KABON, H. (2000): Neue fossile Floren aus dem Nötscher Karbon (2. Teil).- Carinthia II, 190/110, 483-516, Klagenfurt.

VAN AMEROM, H.W.J. \& KABON, H. (2000): Neue fossile Floren aus dem Nötscher Karbon (3. Teil).- Carinthia II, 193/113, 527-560, Klagenfurt.

VESELINOVIĆ, M. (1958): Nov nalazak Dictyodora liebeana (Weiss) u karbonskim škriljcima zapadne Srbije [New find of Dictyodora liebeana (Weiss) in Carboniferous schists of western Serbia - in Serbian].- Zbornik radova geološkog instituta „Jovan Žujuović", 10, 95-97, Beograd.

VESELINOVIĆ, M., ANTONIJEVIĆ, I., MILOŠAKOVIĆ, R., MIĆIĆ, I., KRSTIĆ, B., ČIČULIĆ, M., DIVLJAN, M. \& MASLAREVIĆ, LJ. (1964a): Osnovna geološka karta SFRJ 1:100000. Tumač za list Boljevac K34-8 [Basic Geological Map of SFRY 1:100000, Geology of the Boljevac sheet - in Serbian].- Savezni geološki zavod, Beograd, $62 \mathrm{p}$.

VESELINOVIĆ, M., ANTONIJEVIĆ, I., KRSTIĆ, B., MIĆIĆ, I., MILOŠAKOVIĆ, R., RAKIĆ, B. \& BANKOVIĆ, V. (1964b): Osnovna geološka karta SFRJ 1:100000, list Boljevac K34-8 [Basic Geological Map of SFRY 1:100000, Boljevac sheet - in Serbian].- Savezni geološki zavod, Beograd.

VOZÁROVÁ, A., EBNER, F., KOVÁCS, S., KRÄUTNER, J.G., SZEDERKENYI, T., KRSTIĆ, B., SREMAC, J., ALJINOVIĆ, D., NOVAK, M. \& SKABERNE, D. (2009): Late Variscan (Carboniferous to Permian) environments in the Circum Pannonian Region.- Geologica Carpathica, 60/1, 71-104. doi: 10.2478/v10096-0090002-7

YANG, R.C., JIN, Z.J., VAN LOON, A.J.T., HAN, Z.Z. \& FAN, A.P. (2017): Climatic and tectonic controls of lacustrine hyperpycnite origination in the Late Triassic Ordos Basin, central China: Implications for unconventional petroleum development.AAPG Bulletin, 101/1, 95-117. doi: 10.1306/06101615095

ZAVALA, C., ARCURI, M. \& BLANCO VALIENTE, L. (2012): The importance of plant remains as a diagnostic criteria for the recognition of ancient hyperpycnites.- Revue de Paléobiologie, 11, 457-469.

ZAVALA, C. \& ARCURI, M. (2016): Intrabasinal and extrabasinal turbidites: Origin and distinctive characteristics.- Sedimentary Geology, 337, 36-54. doi: 10.1016/j.sedgeo.2016.03.008

ZAVALA, C. \& PAN, S. (2018): Hyperpycnal flows and hyperpycnites: Origin and distinctive characteristics.- Lithologic Reservoirs, 30/1, 1-27. doi: 10.3969/j. issn.1673-8926.2018.01.001

ZIMMERMANN, F. (1956): Paleobotaniczne zapiski z dolno-śląskiego karbonu [Notes on the paleobotany of the Lower Silesian Carboniferous - in Polish with an English summery].- Biull. Instytutu Geolog., 98, 125-263, Warsaw. 